\title{
High-Affinity Insulin Binding to an Atypical Insulin-like Growth Factor-I Receptor in Human Breast Cancer Cells
}

\author{
Giovanni Milazzo, ${ }^{\star}$ Cecil C. Yip,` Betty A. Maddux," Riccardo Vigneri," and Ira D. Goldfine* \\ *Division of Diabetes and Endocrine Research, Mount Zion Medical Center, University of California, San Francisco, San Francisco, \\ California 94120; ${ }^{\ddagger}$ Banting and Best Department of Medical Research, University of Toronto, Toronto, Ontario, M5G 1L6, \\ Canada; and ${ }^{\S}$ Cattedra di Endocrinologia dell'Universita di Catania, Ospedale Garibaldi, 95123 Catania, Italy
}

\begin{abstract}
We studied the nature of insulin receptor binding in MCF-7 breast cancer cells. In both intact cells and solubilized receptor preparations, high-affinity insulin binding was seen. However, unlabeled insulin-like growth factor-I (IGF-I) was five-fold more potent in inhibiting ${ }^{125} \mathrm{I}$-insulin binding than insulin itself. With monoclonal antibodies to the insulin receptor, $30 \%$ of ${ }^{125} \mathrm{I}$ insulin binding was inhibited. In contrast when $\alpha$-IR3, a monoclonal antibody that recognizes typical IGF-I receptor, was employed over $60 \%$ of ${ }^{125} \mathrm{I}$-insulin binding was inhibited. The B29MAB- ${ }^{125}$ I-insulin photoprobe was then cross-linked to MCF-7 membranes. Cross-linking was inhibited by both unlabeled insulin and IGF-I. Further, the B29-MAB- ${ }^{125}$ I-insulin photoprobe cross-linked to MCF-7 membranes was strongly immunoprecipitated by $\alpha$-IR3. Employing sequential affinity chromatography with insulin-Affi-gel followed by insulin receptor monoclonal antibody agarose, atypical insulin binding activity was separated from insulin receptor binding activity. This atypical receptor had intrinsic tyrosine kinase activity. Both insulin and IGF-I stimulated the phosphorylation of the receptor's $\beta$ subunit. In MCF-7 cells both IGF-I and insulin stimulated $\left.{ }^{3} \mathrm{H}\right]$ thymidine incorporation; $\alpha$-IR3 blocked all of the IGF-I effect but only $50-60 \%$ of the insulin effect. This study demonstrates in MCF-7 cells that, in addition to typical insulin and IGF-I receptors, there is another receptor that binds both insulin and IGF-I with high affinity. (J. Clin. Invest. 1992. 89:899908.) Key words: insulin receptor • insulin-like growth factor-I • oncogene $\bullet$ photocross-linking $\bullet$ tyrosine kinase
\end{abstract}

\section{Introduction}

Receptors that have tyrosine kinase activity in their intracellular domain play a key role in both normal and neoplastic cell growth. The insulin receptor (IR) ${ }^{1}$ belongs to the tyrosine-kinase growth factor receptor family (1-3), and insulin mediates proliferative responses in a variety of both normal and trans-

Address reprint requests to Dr. Milazzo, Division of Diabetes and Endocrine Research, Mount Zion Medical Center, University of California, San Francisco, P.O. Box 7921, San Francisco, CA 94120.

Received for publication 10 July 1991 and in revised form 23 October 1991

1. Abbreviations used in this paper: IGF-I, insulin-like growth factor-I; IR, insulin receptor; MAB, monoazidobenzoyl; WGA, wheat germ agglutinin.

J. Clin. Invest.

(c) The American Society for Clinical Investigation, Inc.

$0021-9738 / 92 / 03 / 0899 / 10 \quad \$ 2.00$

Volume 89, March 1992, 899-908 formed cells $(4,5)$. However, the role of the IR molecule in human neoplasia has not yet been established. Recently, we have reported that overexpression of the IR is a characteristic feature of many human breast cancer specimens (6). By using a specific IR radioimmunoassay, we found that the average IR content of human breast cancer specimens was five- to six-fold higher than that of normal breast tissue. With immunohistochemical analysis we localized the increased expression of the IR to the malignant epithelial cells. The IR content of the breast cancer specimens was positively correlated with tumor grade and tumor size. These observations suggested, therefore, a possible role for IRs in human cancer initiation and/or progression.

Human breast cancer cells in tissue culture are important in vitro models for studying the regulation of breast cancer tissue by hormones and growth factors, and established estrogen-sensitive lines of breast carcinoma cells in tissue culture, have been used to understand the regulation of human breast carcinoma growth by polypeptide growth factors (7). Accordingly, these cells have been employed to study the effect of insulin on the regulation of growth and other cellular functions (8). However, whether insulin mediates the growth of breast cancer cells via the IR is controversial. On one hand, Osborne, Lippman and colleagues have reported that concentrations of insulin as low as 10 pM stimulate the growth of MCF-7 cells, an estrogen-sensitive line that contains relatively high levels of insulin binding $(8,9)$. Further, the effects of insulin on mitogenesis on these cells were not inhibited by the monoclonal antibody $\alpha$-IR3 (10), a specific antagonist of the related insulin-like growth factor-I(IGF-I) receptor (11). These findings have suggested, therefore, that insulin, via its own receptor, regulates growth in MCF-7 cells. On the other hand, two other groups have reported that much higher concentrations of insulin are needed to stimulate the growth of these cells $(12,13)$. Since the related ligand, IGF-I, stimulated the growth of MCF-7 cells at much lower concentrations than insulin, and since insulin interacts with IGF-I receptors, these groups concluded that the effect of insulin on the growth of MCF-7 cells was due to the interaction of insulin with the IGF-I receptor. However, in none of the above studies was insulin binding to receptors in either MCF-7 or other breast cancer cells investigated in detail.

The study of insulin and IGF-I receptors in target cells is complicated both by the similarity of the two ligands, insulin and IGF-I, and the similarity of their two receptors (14). Also, both atypical and/or alternative IGF-I receptors and IGF-I/IR hybrids have been reported in several cell types (15-18). In the present study, in order to investigate the insulin receptor in MCF-7 cells, we employed (a) monoclonal and polyclonal antibodies specific for insulin and IGF-I receptors and $(b)$ photoprobes of insulin and IGF-I. We now find evidence that in MCF-7 cells there is an unusual receptor that has high affinity 
for both insulin and IGF-I. This unusual receptor may signal the effects of both insulin and IGF-I.

\section{Methods}

The following materials were purchased: Dulbecco's modified Eagle's medium (DME H-21), nonessential amino acids, fetal calf serum (FCS), glutamine, penicillin, streptomycin, and trypsin from the Cell Culture Facility, University of California, San Francisco; tissue culture flasks and dishes from Falcon Labware, Los Angeles, CA; MCDB-170 media and bovine pituitary extract from Clonetic Corp., San Diego, CA; epidermal growth factor from Collaborative Research, Bedford, CA; bovine serum albumin (BSA, radioimmunoassay grade), Triton $\mathrm{X}-100$, bacitracin, phenylmethylsulfonyl fluoride (PMSF), transferrin, hydrocortisone, isoproterenol, human $\gamma$-globulin, sonicated salmon sperm DNA, dextran sulfate, poly (Glu-Tyr) 4:1, and porcine insulin were purchased from Sigma Chemical Co., St. Louis, MO; wheat germ agglutinin agarose (WGA) from ICN Biomedicals, Costa Mesa, CA; formamide and proteinase $\mathrm{K}$ from Gibco BRL Life Technologies, Inc., Gaithersburg, MD; Affi-gel 15, dithiothreitol and reagents for SDS PAGE from Bio-Rad Laboratories, Richmond, CA; IGF-I from Eli Lilly \& Co., Indianapolis, IN; ${ }^{125} \mathrm{I}$-labeled insulin (sp act 2,200 Ci/ mmol), $\left[{ }^{3} \mathrm{H}\right]$ thymidine $(82.3 \mathrm{Ci} / \mathrm{mmol})$ and $\left[\gamma^{32} \mathrm{P}\right] \mathrm{ATP}(3,000 \mathrm{Ci} /$ mmol) from New England Nuclear, Boston, MA; ${ }^{125}$ I-labeled IGF-I (sp act $2,000 \mathrm{Ci} / \mathrm{mmol})$ and $\left[\alpha_{-}{ }^{32} \mathrm{P}\right] \mathrm{dCTP}(3,000 \mathrm{Ci} / \mathrm{mmol})$ from Amersham Corp., Arlington Heights, IL.

Sepharose-protein A was from Pharmacia (Canada). The radioactive photoprobe of insulin, $\mathrm{N}^{\mathrm{B} 29}$-monoazidobenzoyl insulin (B29MAB- ${ }^{125}$ I-insulin) was prepared as previously described (19). $\mathrm{N}^{\mathbf{B} 28}$ monoazidobenzoyl IGF-I (B28-MAB- ${ }^{125}$ I-IGF-I) will be described elsewhere.

For most studies we used a line of MCF-7 kindly donated by Dr. I. Perroteau (Universita di Torino, Turin, Italy). Other MCF-7 and ZR75-1 cells were from Cell Culture Facility, University of California, San Francisco; T-47D cells were from Dr. C. Sonnenschein and Dr. A. Soto, Tufts University, Boston, MA. These cell lines were routinely grown in DME H-21 with $10 \%$ fetal calf serum, nonessential amino acids, glutamine, penicillin, and streptomycin. The medium was changed every 2 d. 184 nonimmortalized breast epithelial cells (from Dr. M. Stampfer, Lawrence Berkeley Laboratory, University of California, Berkeley, CA) were cultured as previously indicated (20) in MCDB-170 media, supplemented with bovine pituitary extracts, insulin, epidermal growth factor, hydrocortisone, isoproterenol, and transferrin. Anti-IR monoclonal antibodies were prepared as previously described (21). $\alpha$-IR3, a mouse monoclonal antibody to the IGF-I receptor (11) was a gift from Dr. S. Jacobs (Burroughs Wellcome Co., Research Triangle Park, NC). Antibody to peptide II corresponding to the insulin receptor sequence 241-251 was prepared as previously described (22).

\section{$R N A$ analysis}

Poly(A) ${ }^{+}$RNA was extracted from cell monolayers (typically $10^{8}$ cells) using a new, one-step method as previously described (23). Briefly, adherent cells were released with proteinase $\mathrm{K}$ (final $0.3 \mathrm{mg} / \mathrm{ml}$ ) and solubilized in $1 \%$ sodium dodecyl sulfate. Oligo(dt)-cellulose was directly added to the lysate and incubated overnight at $22^{\circ} \mathrm{C}$. Poly(A) ${ }^{+}$ RNA was eluted from oligo(dt)-cellulose by adding $3 \mathrm{ml}$ of $10 \mathrm{mM}$ Tris with $0.1 \mathrm{mM}$ EDTA and $0.2 \%$ SDS. Poly $(\mathrm{A})^{+}$RNA $(8 \mu \mathrm{g})$ was then electrophoresed on $1 \%$ agarose gel containing $2.2 \mathrm{M}$ formaldehyde and then transferred to nitrocellulose filters.

Northern blot hybridization for insulin receptor mRNA was carried out using two human IR CDNA probes, 18.2 and 13.2 (1 and $4.2 \mathrm{~kb}$, respectively) a kind gift of Dr. G. I. Bell, University of Chicago. Northern blot hybridization for IGF-I receptor mRNA was carried out using an IGF-I receptor cDNA prepared as previously described (24).
These were labeled with $100 \mu \mathrm{Ci}\left[{ }^{32} \mathrm{P}\right] \mathrm{CTP}$ by random primers $(25)$ to a specific activity of $10^{9} \mathrm{cpm} / \mu \mathrm{g}$. The nitrocellulose filters were prehybridized and hybridized as previously described (25). Filters were then washed under high stringency conditions twice for $30 \mathrm{~min}$ at $42^{\circ} \mathrm{C}$ in $1 \times \operatorname{SSC}(20 \times \mathrm{SSC}=3 \mathrm{M} \mathrm{NaCl}, 300 \mathrm{mM} \mathrm{Na}$ citrate, $\mathrm{pH} 7.0)$ with $0.1 \%$ SDS and twice for $30 \mathrm{~min}$ at $50^{\circ} \mathrm{C}$ in $0.5 \times$ SSC with $0.1 \%$ SDS and autoradiographed. In certain studies, low stringency hybridization was carried out by washing the filter four times for $10 \mathrm{~min}$ at room temperature in $1 \times$ SSC with $0.1 \%$ SDS.

\section{${ }^{125}$ I-insulin and ${ }^{125}$ I-IGF-I binding to intact cells}

Cells attached to 24-mm tissue dishes were rinsed twice with $1 \mathrm{ml}$ of phosphate buffered saline (PBS) and incubated for $16 \mathrm{~h}$ at $4^{\circ} \mathrm{C}$ in 0.5 $\mathrm{ml}$ of binding buffer containing $120 \mathrm{mM} \mathrm{NaCl}, 1.2 \mathrm{mM} \mathrm{MgSO}_{4}, 15$ $\mathrm{mM} \mathrm{Na}$ acetate, $5 \mathrm{mM} \mathrm{KCl}, 10 \mathrm{mM}$ glucose, $1 \mathrm{mM}$ EDTA, $10 \mathrm{mg} / \mathrm{ml}$ BSA, $1 \mathrm{mg} / \mathrm{ml}$ bacitracin, $50 \mathrm{mM}$ Hepes, $\mathrm{pH} 7.8$, and $40 \mathrm{pM}^{125} \mathrm{I}$-insulin with or without increasing concentration of unlabeled hormones or antibodies. The incubation medium was then removed, the monolayers were washed twice, the cell lysed with $0.03 \%$ SDS and the radioactivity associated with cell lysate was measured in a $\gamma$-scintillation counter (Beckman Instruments, Inc., Palo Alto, CA). Binding was corrected for nonspecific ${ }^{125}$ I-insulin binding ( $<5 \%$ of total binding) as determined in the presence of $1 \mu \mathrm{M}$ unlabeled insulin. Specific ${ }^{125}$ I-insulin binding/mg protein was $7.5 \%, 5.4 \%, 17.4 \%$ and $1.2 \%$ total radioactivity in MCF-7, T-47D, ZR-75-1, and 184 cells, respectively.

Specific ${ }^{125}$ I-IGF-I binding to MCF-7 cells was carried out in the same manner. Nonspecific binding ( $<5 \%$ of total binding) was determined in the presence of $100 \mathrm{nM}$ unlabeled hormone. Specific ${ }^{125} \mathrm{I}$ IGF-I binding/mg protein was $83.9 \%, 31.6 \%, 16.7 \%$, and $50 \%$ total radioactivity in MCF-7, T-47D, ZR-75-1, and 184 cells, respectively.

\section{MCF-7 membrane preparation}

Confluent cells from five flasks $\left(150 \mathrm{~cm}^{2}\right)$ were harvested and centrifuged. The cell pellet was resuspended in $50 \mathrm{mM}$ Tris buffer, $\mathrm{pH} 7.9$, containing $10 \mathrm{mM}$ benzamidine, $30 \mu \mathrm{g} / \mathrm{ml}$ aprotinin, $0.2 \mathrm{mg} / \mathrm{ml}$ bacitracin, $10 \mathrm{mM}$ PMSF, sonicated three times for $20 \mathrm{~s}$, and centrifuged for $10 \mathrm{~min}$ at $2,500 \mathrm{rpm}$. The pellet obtained was treated as above one more time. The supernatants of each centrifugation were pooled and centrifuged at $11,000 \mathrm{rpm}$ for $10 \mathrm{~min}$. The pellet was resuspended in 1-2 ml of Tris buffer, aliquoted in 100- $\mu$ l fractions and microfuged for $30 \mathrm{~min}$. The supernatant was finally removed, and the pellet was stored at $-70^{\circ} \mathrm{C}$.

\section{Photoaffinity labeling and immunoprecipitation}

Membranes from MCF-7 cells were incubated overnight at $4^{\circ} \mathrm{C}$ at a final protein concentration of $0.3-0.5 \mathrm{mg} / \mathrm{ml}$ with the ${ }^{125}$ I-labeled photoprobe in $50 \mathrm{mM}$ Tris- $\mathrm{HCl}$ buffer, $\mathrm{pH} \mathrm{7.4,} \mathrm{containing} \mathrm{bacitracin} \mathrm{(1}$ $\mathrm{mg} / \mathrm{M} \mathrm{ml})$, BSA $(0.01 \%)$, aprotinin $(0.05 \mathrm{mg} / \mathrm{ml})$, benzamidine $(10$ $\mathrm{mM})$, pepstatin $(1.35 \mu \mathrm{g} / \mathrm{ml})$, leupeptin $(0.95 \mu \mathrm{g} / \mathrm{ml})$, and PMSF (1 $\mathrm{mM}$ ). After photolysis (19), the membrane pellet, recovered after centrifugation in a Biofuge for $30 \mathrm{~min}$, was either solubilized in SDS sample buffer for SDS-PAGE in $7.2 \%$ gel, or solubilized in Triton X-100 to be used for immunoprecipitation. Solubilization in Triton was carried out at a protein concentration of $1.2 \mathrm{mg} / \mathrm{ml}$ in $1 \%$ Triton X-100 in 50 $\mathrm{mM}$ Hepes buffer, $\mathrm{pH} 7.4$, containing $\mathrm{NaCl}(150 \mathrm{mM})$, bacitracin $(0.08$ $\mathrm{mg} / \mathrm{ml})$, aprotinin $(0.01 \mathrm{mg} / \mathrm{ml})$, benzamidine $(10 \mathrm{mM})$, pepstatin $(1.35 \mu \mathrm{g} / \mathrm{ml})$, leupeptin $(0.95 \mu \mathrm{g} / \mathrm{ml})$, and PMSF $(1 \mathrm{mM})$. Solubilization was carried out for $90 \mathrm{~min}$ in an ice bath followed by centrifugation at $29,000 \mathrm{~g}$ for $23 \mathrm{~min}$. Aliquots of the supernatant, each containing about $1.5 \times 10^{5} \mathrm{cpm}$, were incubated overnight at $4^{\circ} \mathrm{C}$ with $10 \mu \mathrm{g}$ of monoclonal antibody to IR, $1 \mu \mathrm{g}$ of $\alpha$-IR3, or $50 \mu \mathrm{g}$ of immunoglobulin from the human polyclonal antiserum to the IR or normal human immunoglobulin. Samples were then incubated with Sepharose-protein $\mathrm{A}(7 \mathrm{mg})$ for $90 \mathrm{~min}$ at $4^{\circ} \mathrm{C}$. The immunocomplex bound to the Sepharose-protein A was solubilized for SDS-PAGE in $7.2 \%$ gel under reducing conditions. 
Radioautograms of the dry gels were obtained with X-Omat AR film (Eastman Kodak Co., Rochester, NY) and Lightening-Plus enhancing screens. Exposure time ranged from 3 to $5 \mathrm{~d}$.

\section{Receptor purification by affinity chromatography}

Step 1. Confluent $150-\mathrm{cm}^{2}$ flasks of MCF-7 cells were solubilized in 50 $\mathrm{mM}$ Hepes buffer $\mathrm{pH} 7.6$ containing $1 \mathrm{mg} / \mathrm{ml}$ bacitracin, $1 \mathrm{mM}$ PMSF, and $1 \%$ Triton $\mathrm{X}-100$ for $60 \mathrm{~min}$ at $4^{\circ} \mathrm{C}$. A clear supernatant was obtained by centrifugation at $100,000 \mathrm{~g}$ for $35 \mathrm{~min}$ at $4^{\circ} \mathrm{C}$. The supernatant was then applied to a 1-ml WGA agarose column which had been previously equilibrated with WGA column buffer containing 150 $\mathrm{mM} \mathrm{NaCl}, 0.1 \%$ Triton X-100, $1 \mathrm{mM}$ PMFS, and $50 \mathrm{mM}$ Hepes, $\mathrm{pH}$ 7.6. Glycoproteins were eluted with the same buffer containing $0.3 \mathrm{M}$ $\mathrm{N}$-acetyl D-glucosamine (26).

Step 2 . The fractions with insulin-binding activity were pooled and applied to a $2.5-\mathrm{ml}$ column composed of insulin coupled to Affi-gel 15 (27). After an 18 -h incubation at $4^{\circ} \mathrm{C}$, the pass-through of the insulinAffi gel column was collected, the column was washed with $50 \mathrm{mM}$ Tris $\mathrm{HCl}$ buffer, $\mathrm{pH} \mathrm{7.4,} \mathrm{containing} 1 \mathrm{M} \mathrm{NaCl}, 0.1 \%$ Triton X-100, and 1 mM PMFS, and then eluted with $50 \mathrm{mM} \mathrm{Na-acetate} \mathrm{buffer,} \mathrm{pH} \mathrm{5.0,}$ containing $1 \mathrm{M} \mathrm{NaCl}, 0.1 \%$ Triton X-100, and $1 \mathrm{mM}$ PMSF. Fractions were collected in tubes containing $0.1 \mathrm{ml}$ of $1 \mathrm{M}$ Tris- $\mathrm{Cl}$ buffer $\mathrm{pH} 8$.

Step 3. The fractions with insulin-binding activity were applied to a column of agarose coupled to monoclonal antibody 51 directed at the human IR $\alpha$ subunit (28). The pass-through was collected and applied to a WGA column as described in step 1 . The column was washed with column buffer composed of $50 \mathrm{mM}$ Hepes, pH 7.6, $1 \mathrm{M} \mathrm{NaCl}, 0.1 \%$ Triton X-100, $1 \mathrm{mg} / \mathrm{ml}$ bacitracin, and $1 \mathrm{mM}$ PMSF. The IR was eluted with $1.5 \mathrm{M} \mathrm{MgCl}_{2}, 0.12 \mathrm{M}$ sodium tetraborate, $0.1 \%$ Triton $\mathrm{X}-100, \mathrm{pH}$ 6.5. Eluted fractions were diluted 10-fold with washing buffer and finally applied to WGA column as described in step 1.

\section{${ }^{125}$ I-insulin and ${ }^{125}$ I-IGF-I binding to affinity-purified, solubilized receptors}

Insulin-binding activity was measured at each purification step by incubating the receptor preparation at $4^{\circ} \mathrm{C}$ for $16 \mathrm{~h}$ with ${ }^{125} \mathrm{I}$-labeled porcine insulin $(40 \mathrm{pM})$ in a final volume of $240 \mu \mathrm{l}$ of binding buffer (100 mM Hepes, pH 7.9, $120 \mathrm{mM} \mathrm{NaCl}, 1.2 \mathrm{mM} \mathrm{MgCl}, 2 \mathrm{mM}$ $\mathrm{MnCl}_{2}, 2.5 \mathrm{mM} \mathrm{KCl}, 0.5 \mathrm{mM} \mathrm{Na}$ acetate, $1 \mathrm{mM}$ EDTA, $1 \mathrm{mg} / \mathrm{ml}$ bacitracin, $10 \mathrm{mg} / \mathrm{ml} \mathrm{BSA}$ ) in the presence or absence of excess unlabeled insulin. Carrier human $\gamma$-globulin $(10 \mathrm{mg} / \mathrm{ml})$ was added to each tube. $0.2 \mathrm{ml}$ of $22 \%$ polyethyleneglycol (PEG) 6000 was then added and incubated for $15 \mathrm{~min}$ at $4^{\circ} \mathrm{C}$. After centrifugation, precipitates were washed once with $11 \%$ PEG and recentrifuged, and the supernatant was discarded and the pellet was counted. Specific binding was obtained by subtracting binding with ${ }^{125} \mathrm{I}$-insulin plus unlabeled insulin from binding with ${ }^{125}$ I-insulin alone. Specific ${ }^{125}$ I-IGF-I binding to soluble receptors was carried out in the same manner.

\section{Tyrosine kinase studies}

Autophosphorylation of atypical IGF-I receptors. Aliquots $(20 \mu \mathrm{l})$ of purified atypical IGF-I receptor preparations obtained as described above, were preincubated with $2 \mathrm{mM} \mathrm{MnCl}$ and $100 \mathrm{nM}$ of either insulin or IGF-I in a total volume of $25 \mu \mathrm{l}$ of WGA buffer. After $60 \mathrm{~min}$ at $20^{\circ} \mathrm{C}$, the phosphorylation reaction was initiated by adding ATP $(10$ $\mu \mathrm{M})$ and $1 \mu \mathrm{Ci}\left[\gamma^{32}-\mathrm{P}\right] \mathrm{ATP}$. After $60 \mathrm{~min}$ at $20^{\circ} \mathrm{C}$, samples were added to $10 \mu \mathrm{l}$ of $4 \times$ Laemmli buffer containing $100 \mathrm{mM}$ dithiothreitol and boiled for $5 \mathrm{~min}$. Phosphorylated receptor preparations were analyzed on $7.5 \%$ SDS-PAGE under reducing conditions. Radioautograms of the dry gels were obtained as described above.

Artifical substrate phosphorylation. For studies of exogenous substrate phosphorylation, atypical IGF-I receptor preparations in $20 \mu \mathrm{l}$ of WGA buffer were preincubated for $60 \mathrm{~min}$ at $20^{\circ} \mathrm{C}$ with increasing concentrations of either insulin or IGF-I in presence of $2 \mathrm{mM} \mathrm{MnCl}$ and $10 \mathrm{mM} \mathrm{MgCl}_{2}$. Next, ATP $(10 \mu \mathrm{M}), 1 \mu \mathrm{Ci}\left[\gamma^{32}\right.$-P]-ATP and 1 $\mathrm{mg} / \mathrm{ml}$ of the synthetic substrate poly(Glu-Tyr) 4:1 were added, and the

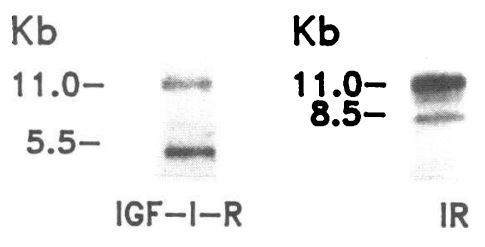

Figure 1. Northern blot analysis of IGF-I $(A)$ and insulin $(B)$ receptors mRNA. Poly $(\mathrm{A})^{+}$RNA was prepared from MCF-7 cells and $(8 \mu \mathrm{g})$ subjected to agarose gel electrophoresis followed by transfer to nitro-

cellulose filters and hybridization utilized with labeled insulin or IGF-I receptor cDNA.

incubation was continued for a further $60 \mathrm{~min}$ at $20^{\circ} \mathrm{C}$. The reaction was stopped by the addition of a solution at $4^{\circ} \mathrm{C}$ containing a final concentration of $10 \mathrm{mM}$ ATP, $0.1 \mathrm{mM}$ EDTA, and $0.5 \%$ BSA. Finally, $15-\mu \mathrm{l}$ aliquots were spotted in 4- $\mathrm{cm}^{2}$ disks of $3 \mathrm{M}$ paper (Whatman, Inc., Clifton, NJ) and dried. Disks were washed in four changes of $10 \%$ TCA containing $20 \mathrm{mM}$ sodium pyrophosphate and in a final acetone wash. Radioactivity was determined by scintillation counting.

\section{DNA synthesis}

$40 \times 10^{3}$ cells were plated in 24-well tissue culture plates in their regular growth medium. After $48 \mathrm{~h}$, the medium was removed and replaced by DME $\mathrm{H}-21$ containing $0.1 \% \mathrm{BSA}$ and $10 \mu \mathrm{g} / \mathrm{ml}$ transferrin. $72 \mathrm{~h}$ later, variable concentrations of either insulin, IGF-I, or $\alpha$-IR 3 were added in fresh medium. After $24 \mathrm{~h}, 0.5 \mu \mathrm{Ci}$ of $\left[{ }^{3} \mathrm{H}\right.$ ]thymidine were added to each well for a $2 \mathrm{~h}$. Cells were then harvested, and the rate of DNA synthesis was measured as described previously (12).

\section{Other methods}

Proteins were measured by the method of Lowry et al. (29). Insulin receptor radioimmunoassay was performed as previously described (30).

\section{Results}

Insulin and IGF-I receptor $M R N A$ content in MCF-7 cells. Poly(A) ${ }^{+}$RNA was extracted from MCF-7 cells and subjected to agarose gel electrophoresis and then transferred to nitrocellulose filters. The mRNA was probed with specific ${ }^{32} \mathrm{P}$ cDNAs for either insulin or IGF-I receptors. Under high stringency conditions, typical bands at 11 and $8.5 \mathrm{~kb}$ were seen for the IR receptor and at 11 and $5.5 \mathrm{~kb}$ for the IGF-I receptor (Fig. 1). The same pattern of bands for both receptors was seen when low stringency conditions were used (data not shown).

Characteristics of ${ }^{125}$ I-insulin binding to $M C F-7$ and other cells. We first measured ${ }^{125} \mathrm{I}$-insulin binding to human MCF-7 breast cancer cells. This binding was inhibited by unlabeled insulin with a half-maximal effect occurring at $2 \mathrm{nM}$ indicating that these cells have high-affinity insulin binding (Fig. $2 \mathrm{~A}$ ). Surprisingly, unlabeled IGF-I, which typically competes for ${ }^{125}$ I-insulin binding to the typical IR with a potency of $\sim 1 \%$ of insulin (31), was more potent than insulin in competing for ${ }^{125} \mathrm{I}$-insulin binding to MCF-7 cells than insulin itself. The halfmaximal effect of IGF-I occurred at $0.4 \mathrm{nM}^{2}$

In order to determine whether this unusual ${ }^{125} \mathrm{I}$-insulin binding was due to the membrane environment of MCF-7 cells, the

2. The majority of studies were carried out with MCF-7 cells obtained from Dr. I. Perroteau, Turin, Italy. Similar effects of insulin and IGF-I on ${ }^{125}$ I-insulin binding were also seen with MCF-7 cells obtained from the Tissue Culture Facility, University California, San Francisco. 

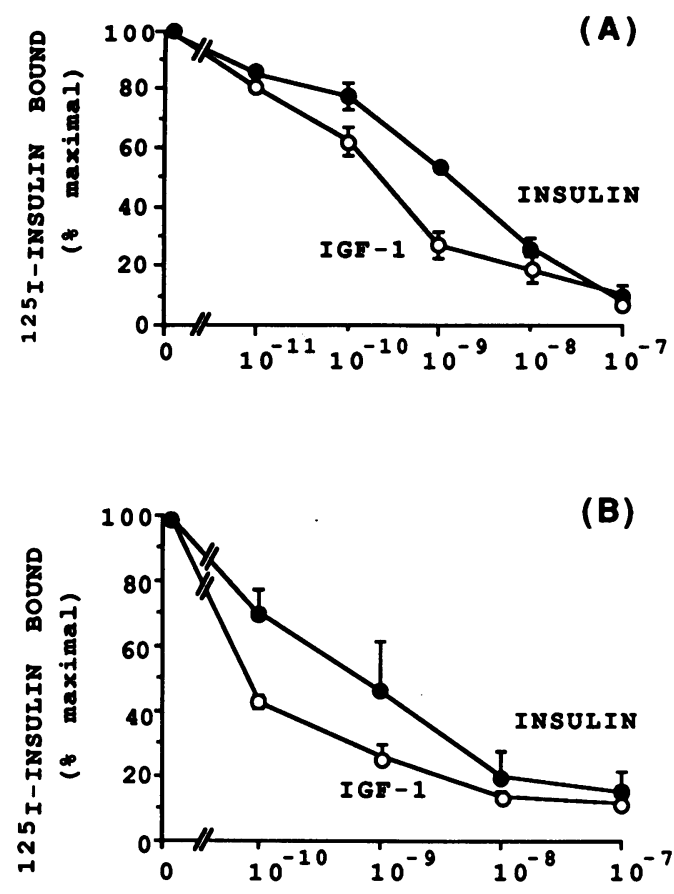

(M)

Figure 2. Inhibition by insulin and IGF-I of ${ }^{125} \mathrm{I}$-insulin binding to intact MCF-7 cells and MCF-7 wheat germ extracts. $(A)$ Cells were plated in culture dishes and specific ${ }^{125}$ I-insulin binding was then measured. Binding is expressed as a percentage of maximal specific ${ }^{125}$ I-insulin binding. Each point is the mean \pm SEM of 6 separate experiments in triplicate. $(B)$ MCF-7 cells were solubilized with $1 \%$ Triton X-100 and the solubilized material was applied to a WGA column. ${ }^{125}$ I-insulin $(20,000 \mathrm{cpm})$ was incubated with receptors in the presence of different concentrations of unlabeled insulin and IGF-I for $16 \mathrm{~h}$ at $4^{\circ} \mathrm{C}$. The percentage of maximal specific binding of ${ }^{125} \mathrm{I}-$ labeled insulin is plotted against the peptide concentrations. Each point is the mean \pm SEM of two separate experiments performed in duplicate.

cells were solubilized in $1 \%$ Triton X-100 and partially purified by affinity chromatography with WGA. When ${ }^{125}$ I-insulin binding was carried out with this receptor preparation, high-affinity insulin binding was again seen. As with intact cells, unlabeled IGF-I was more potent than insulin in inhibiting ${ }^{125}$ I-insulin binding (Fig. 2 B).

In order to determine whether this unusual ${ }^{125}$ I-insulin binding observed in MCF-7 cells was seen in other cells, we studied both a nonmalignant human breast epithelial cell line (184) and two human breast cancer cell lines (T-47D and ZR-75-1) (Fig. 3). In all three cell lines ${ }^{125}$ I-insulin binding was inhibited by unlabeled insulin with a half-maximum effect occurring at 300,500 , and $<200 \mathrm{pM}$ in $184, \mathrm{~T}-47 \mathrm{D}$, and ZR-75-1 cells, respectively. In contrast to MCF-7 cells, in these three cell lines, unlabeled IGF-I only weakly competed for ${ }^{125}$ I-insulin binding; the potency of unlabeled IGF-I was 1\% that of insulin.

Influence of anti-receptor monoclonal antibodies on ${ }^{125}$ I-insulin binding to MCF-7 and other breast cell lines. To further understand the nature of ${ }^{125}$ I-insulin binding to MCF-7 cells, we employed three monoclonal antibodies directed against the $\alpha$ subunit of the IR (MA-10, MA-51, MA-20) and one antibody directed against the $\alpha$ subunit of the IGF-I receptor ( $\alpha$-IR3)
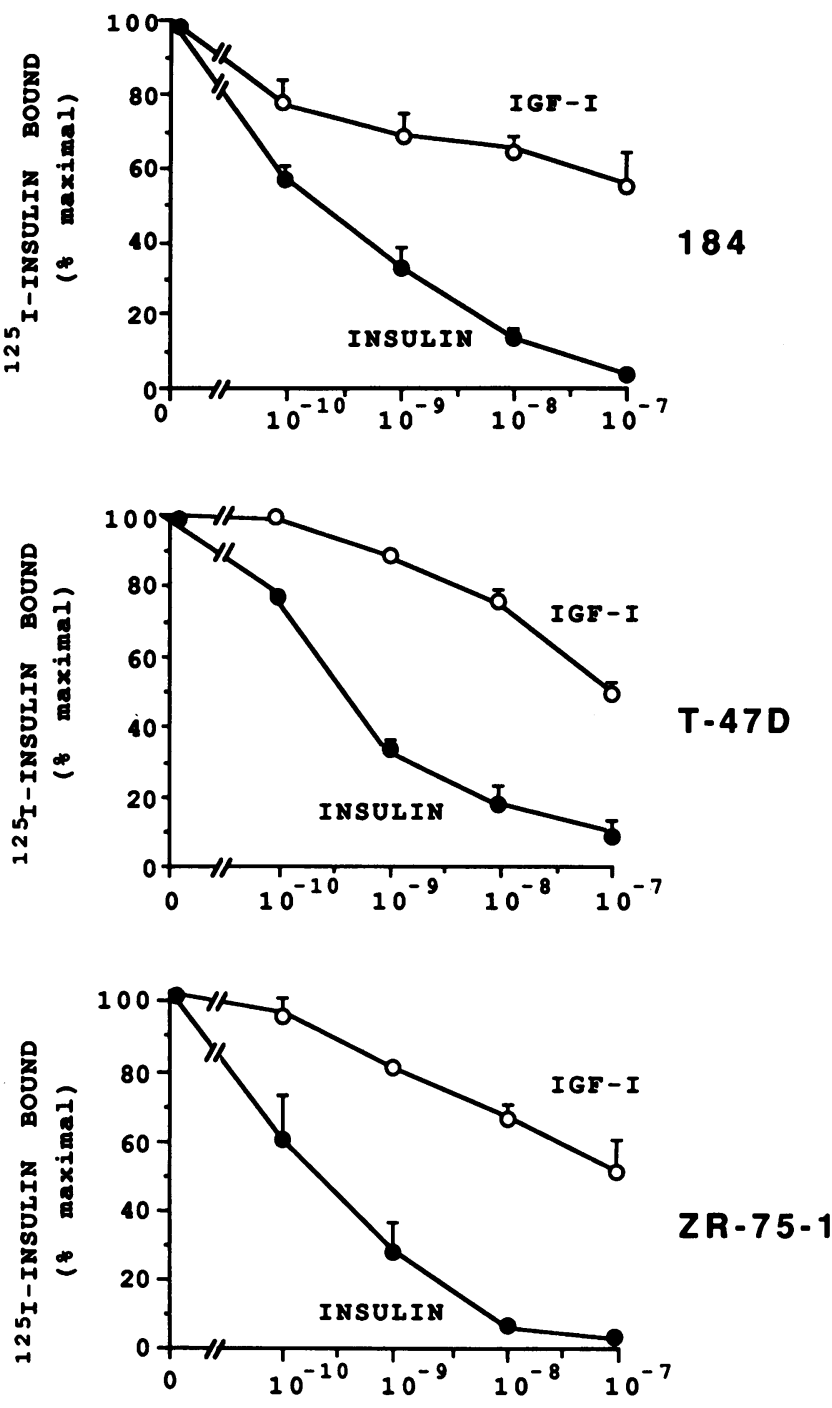

(x)

Figure 3. Inhibition by unlabeled insulin and IGF-I of ${ }^{125} \mathrm{I}$-insulin binding to the nontransformed breast cell line (184) and breast cancer cell lines (T-47D and ZR-75-1). Cells were plated in culture dishes and specific ${ }^{125} \mathrm{I}$-insulin binding was then measured. Binding is expressed as a percentage of maximal specific ${ }^{125}$ I-insulin binding. Each point is mean $\pm \mathrm{SEM}$ of two separate experiments performed in triplicate.

(Fig. 4). At $100 \mathrm{nM}$ (the highest concentration tested) $\alpha$-IR3 inhibited $60 \%$ of ${ }^{125}$ I-insulin binding to MCF-7 cells with a potency that was similar to that of insulin. In contrast, at 100 $\mathrm{nM}$ the monoclonal antibodies against the IR only inhibited ${ }^{125}$ I-insulin binding to MCF-7 cells by $\sim 30 \%$. These studies indicated, therefore, that ${ }^{125}$ I-insulin binding to MCF-7 cells was not predominantly to the insulin receptor but rather to another receptor which was more similar to the IGF-I receptor.

Other studies were carried out with ${ }^{125} \mathrm{I}$-insulin binding to receptors in T47D and ZR-75-1 breast cells. In contrast to MCF-7 cells, in these cells two monoclonal antibodies to the IR (MA-10, MA-51) completely inhibited ${ }^{125}$ I-insulin binding whereas $\alpha$-IR3 was nearly without effect (Fig. 5).

${ }^{125}$ I-IGF-I binding to MCF-7 cells. We next studied the binding of ${ }^{125}$ I-IGF-I to MCF-7 cells (Fig. 6). Both unlabeled 


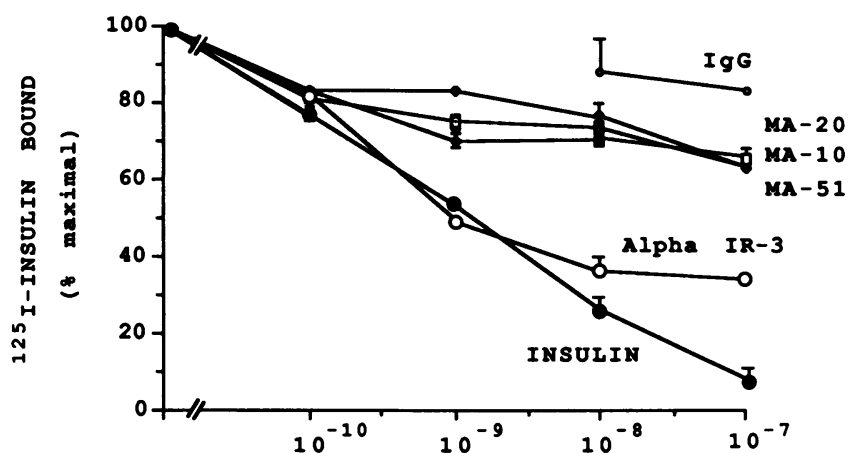

(x)

Figure 4. Inhibition of ${ }^{125} \mathrm{I}$-insulin bound to MCF-7 cells by five monoclonal antibodies, mouse IgG, and insulin. Cells were plated in culture dishes and specific ${ }^{125} \mathrm{I}$-insulin binding was then measured. Binding is expressed as a percentage of maximal specific ${ }^{125} \mathrm{I}$-insulin binding. Each point is the mean \pm SEM of three separate experiments performed in triplicate.

IGF-I and $\alpha$-IR 3 completely inhibited the binding of ${ }^{125}$ I-IGF-I to MCF-7 cells with half-maximal effect occurring at $1 \mathrm{nM}$ and $500 \mathrm{pM}$, respectively. Unlabeled insulin inhibited ${ }^{125} \mathrm{I}-\mathrm{IGF}-\mathrm{I}$ binding with half-maximal effect occurring at $400 \mathrm{nM}$. Monoclonal MA-10 and normal mouse IgG were without effect. These studies indicated, therefore, that MCF-7 cells have a normal IGF-I receptor which has only weak affinity for insulin.
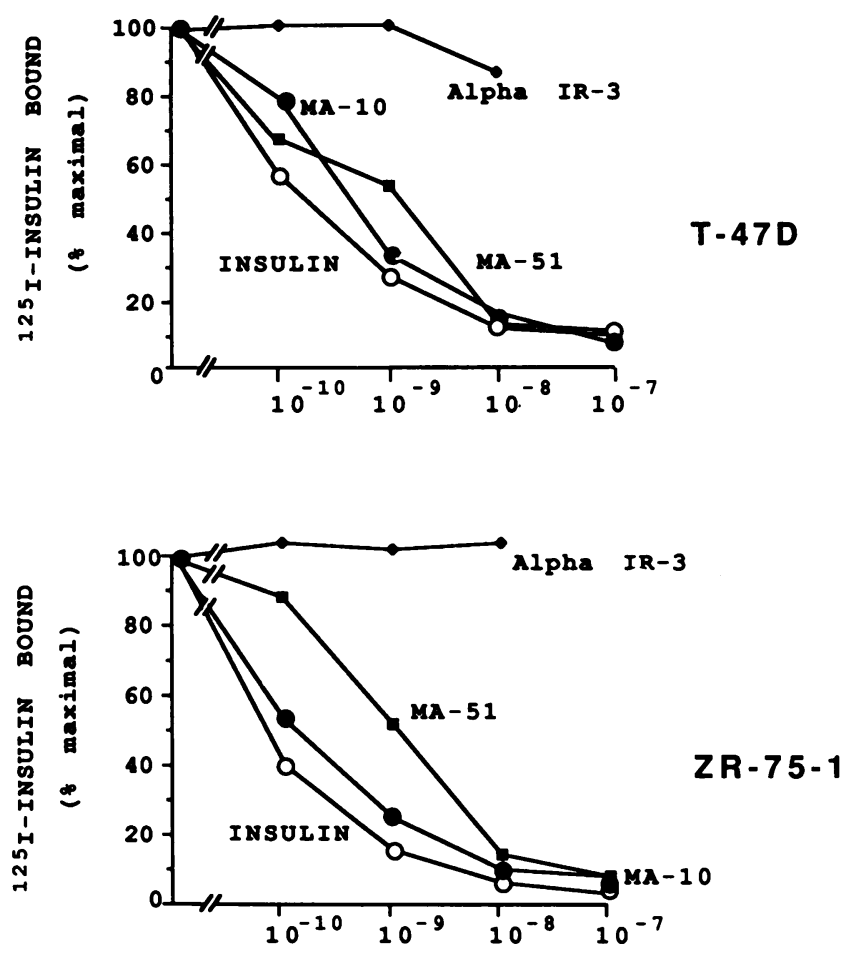

(M)

Figure 5. Inhibition of ${ }^{125} \mathrm{I}$-insulin bound to T-47D and ZR-75-1 cells by monoclonal antibodies and insulin. Cells were plated in culture dishes and specific ${ }^{125}$ I-insulin binding was then measured. Binding is expressed as a percentage of maximal specific ${ }^{125} \mathrm{I}$-insulin. A representative experiment is shown. Each point is the mean of triplicate determinations.

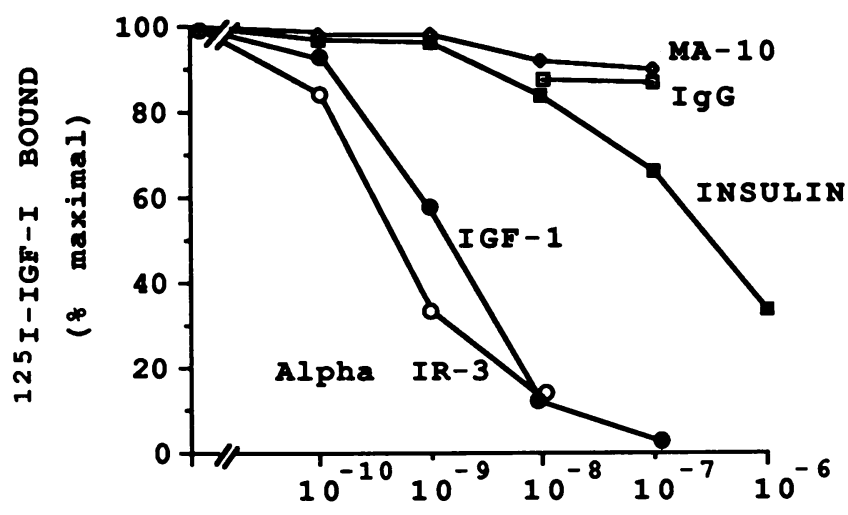

(M)

Figure 6. Inhibition of ${ }^{125}$ I-IGF-I to MCF-7 cells by IGF-I, insulin, monoclonal antibodies, and IgG. Cells were plated in culture dishes and specific ${ }^{125} \mathrm{I}-\mathrm{IGF}-\mathrm{I}$ binding was then measured. Binding is expressed as a percentage of maximal specific ${ }^{125}$ I-IGF-I binding. A representative experiment is shown. Each point is mean of triplicate determinations.

Photoaffinity labeling. As an alternative approach to understand the nature of insulin binding to MCF-7 cells, we carried out a series of experiments whereby we photoaffinity-labeled membranes prepared from MCF-7 cells (Fig. 7). Membranes photolabeled with B29-MAB- ${ }^{125}$ I-insulin and then analyzed by SDS-PAGE under reducing conditions showed an intensely labeled band of $120 \mathrm{kD}$. The labeling of this band was blocked by both insulin and IGF-I. A similar labeled band was observed when membranes were photoaffinity-labeled with B28-MAB${ }^{125} \mathrm{I}$-IGF-I. The labeling of this band was blocked by IGF-I but not by insulin. These observations therefore are consistent with the results obtained from ligand binding studies shown in Figs. 2 and 6.

We next immunoprecipitated the MCF-7 membrane receptors photoaffinity-labeled with either B29-MAB- ${ }^{125} \mathrm{I}$-insulin or B28-MAB- ${ }^{125} \mathrm{I}-\mathrm{IGF}-\mathrm{I}$ (Fig. 8). The precipitates were analyzed by SDS-PAGE after reduction. When membranes were photolabeled with B29-MAB ${ }^{125}$ I-insulin, a labeled band of 120

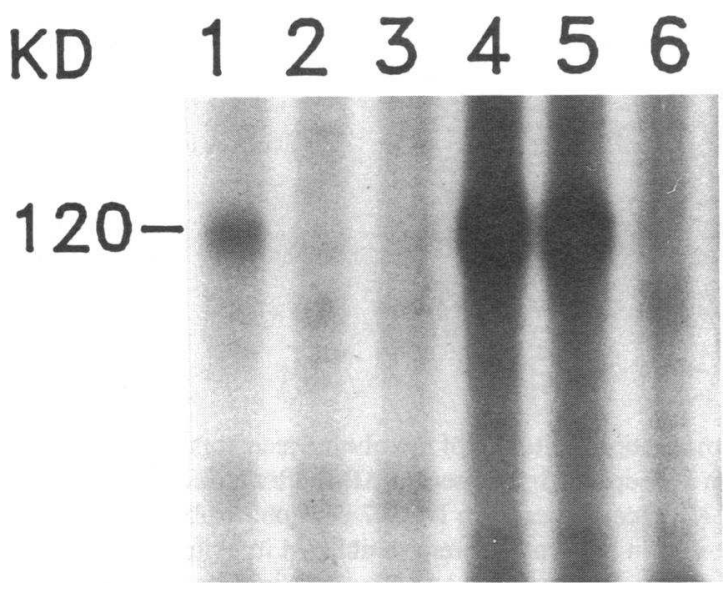

Figure 7. Photoaffinity-labeling of MCF-7 cell membranes with photoprobes of insulin (lanes 1-3) and IGF-I (lanes 4-6) in the presence of either $1 \mu \mathrm{M}$ unlabeled insulin (lanes 2 and 5) or unlabeled IGF-I (lanes 3 and 6). The photolabeled membranes were solubilized for SDS-PAGE in $7.2 \%$ gel under reducing conditions. 
INSULIN

IGF-I

KD

$120-$

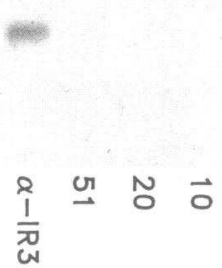

MONOCLONAL ANTIBODIES

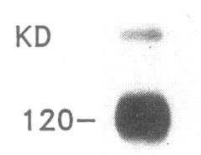

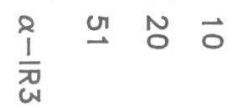

Figure 8. Immunoprecipitation of receptors from MCF-7 membranes, after photocross-linking with insulin photoprobe (left) or IGF-I photoprobe (right). Immunoprecipitation was carried out using monoclonal antibodies directed against either the IR $(51=$ antibody MA-51; 20 = antibody MA-20; 10 = antibody MA-10) or the IGF-I receptor $(\alpha$-IR3). The immunoprecipitate was separated by SDSPAGE on $7.2 \%$ gel.

$\mathrm{kD}$ was precipitated by the IGF-I receptor monoclonal antibody $\alpha$-IR3. In contrast, precipitation obtained with IR monoclonal antibodies showed little or no labeled 120-kD band (Fig. 8, left panel).

When membranes were photolabeled with the IGF-I photoprobe, a $120-\mathrm{kD}$ band precipitated by the monoclonal antibody $\alpha$-IR3 was much more intensely labeled than with the insulin photoprobe. In addition, a very weakly labeled band of $\sim 200 \mathrm{kD}$ was also detected. This band most likely is an IGF-I receptor precursor. Precipitation of the labeled $120-\mathrm{kD}$ band by the other antibodies was minimal (Fig. 8, right panel). These observations are in agreement with the data on ligand binding

KD

$$
\text { MCF }-7
$$

HTC-IR which demonstrated that binding of insulin to MCF-7 cells was primarily to receptors recognized by antibody $\alpha$-IR3 to the IGF-I receptor, and not by antibodies to the IR.

We have previously reported that residues $241-251$ of the IR $\alpha$ subunit may play an important role in insulin binding (32). In a previous study (22) we observed that antiserum AP-II raised against a synthetic peptide containing this sequence, while neither reactive towards the native IR nor inhibitory to insulin binding, was able to precipitate the denatured $\alpha$ subunit of the IR photolabeled with B29-MAB- ${ }^{125}$ I-insulin. Accordingly, MCF-7 membranes were photolabeled with the insulin

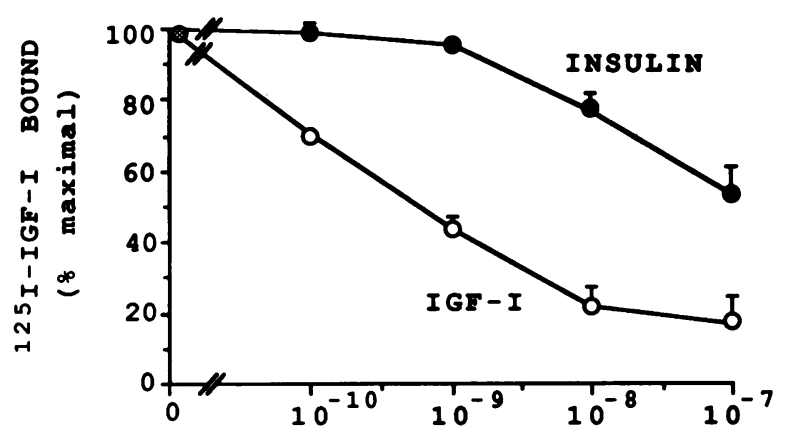

A

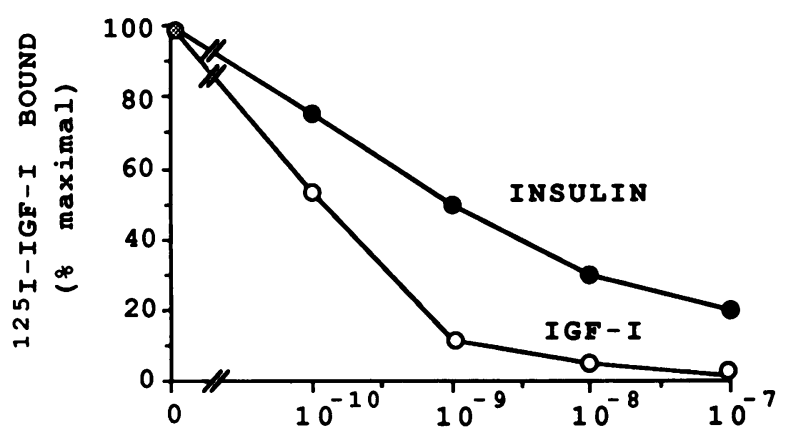

B

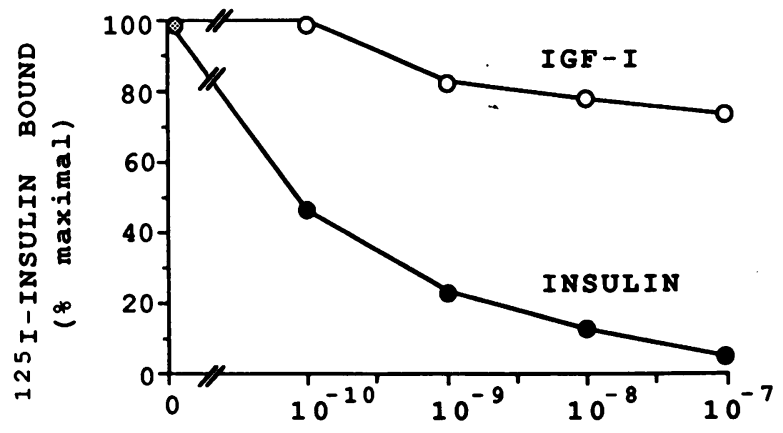

(M)

Figure 10. Separation of the insulin, IGF-I, and typical receptor binding activities by affinity chromatography. MCF-7 cells were solubilized and the insulin binding activity subjected to affinity chromatography on insulin-Affi-gel followed by chromatography on IR monoclonal antibody-agarose. $(A)$ Specific IGF-I binding to IGF-I receptors in the pass-through of the insulin-Affi-gel column. $(B)$ Specific IGF-I binding to atypical receptors in the pass-through of the IR monoclonal antibody column. $(C)$ Specific insulin binding to insulin receptors eluted from the insulin receptor monoclonal antibody column. 


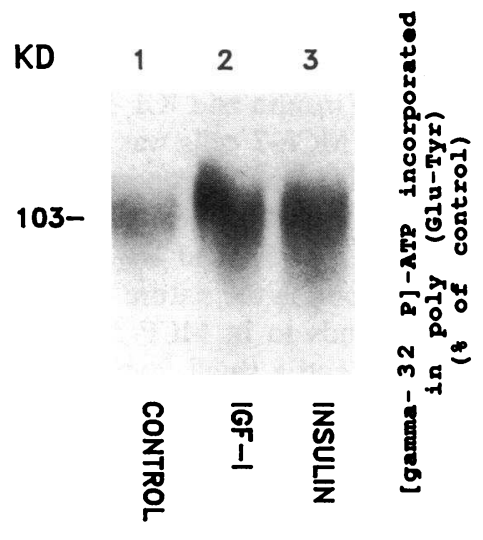

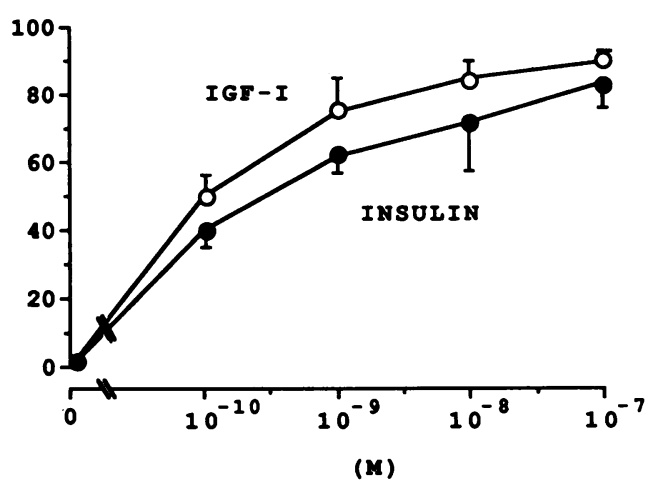

Figure 11. IGF-I and insulin-stimulated tyrosine phosphorylation of the atypical receptor. Left: Autophosphorylation of the atypical receptor. The atypical receptor was allowed to undergo phosphorylation in absence (lane 1 ) or presence of $100 \mathrm{nM}$ of either IGF-I (lane 2) or insulin (lane 3 ), and analyzed by SDSPAGE under reducing conditions. Right: Tyrosine kinase activity of the atypical IGF-I receptor. The atypical receptor was incubated in the presence of increasing concentrations of either insulin or IGF-I, and $1 \mu \mathrm{Ci}\left[\gamma^{32}\right.$-P]-ATP, with $10 \mu \mathrm{M}$ unlabeled ATP, and $1 \mathrm{mg} / \mathrm{ml}$ of the substrate poly (Glu-Tyr) 4:1. Values are the mean \pm SD for a representative of three experiments carried out in quadruplicate. photoprobe, solubilized, and, after denaturation, immunoprecipitated with antiserum AP-II. Fig. 9 shows the absence of the labeled $120-\mathrm{kD}$ band in the precipitate. Under similar conditions the antiserum AP-II precipitated a highly labeled band of $135 \mathrm{kD}$ from membranes prepared from HTC-IR rat hepatoma cells that have been transfected with human IR cDNA, and express IR (33). The precipitation of the 135-kD band was inhibited by an excess of the synthetic peptide (Fig. 9). These data provide further evidence that the binding of insulin to MCF-7 cells predominantly occurred on receptors that were not typical IRs.

Two other polyclonal antisera to the IR were studied; an antiserum ARS- 2 to the IR from a patient with insulin resistance (22) and an antiserum raised to the carboxyl terminal of the IR $\beta$ subunit (34). Neither antisera reacted with the MCF-7 receptors photolabeled with B29-MAB-125 I-insulin (data not shown).

Purification of the atypical IGF-I receptor by affinity chromatography. After MCF-7 cells were solubilized and glycoproteins purified by WGA affinity chromatography, they were subjected to insulin affinity chromatography on insulin-Affigel column. The pass-through of this column contained receptors that bound IGF-I with high affinity (Fig. $10 \mathrm{~A}$ ), and this binding was weakly inhibited by insulin ( $<1 \%$ the potency of IGF-I). The material eluted from the insulin-Affi-gel column was then subjected to affinity chromatography on a column of IR monoclonal antibody MA-51 agarose. The pass-through from this column bound IGF-I with high affinity, but unlike typical IGF-I receptors, this binding was inhibited by insulin with a potency of about $10 \%$ that of IGF-I (Fig. $10 \mathrm{~B}$ ). High-affinity insulin binding was also seen in the fraction, but unlabeled IGF-I was more potent than insulin in inhibiting ${ }^{125} \mathrm{I}-\mathrm{in}$ sulin binding (data not shown). The receptor eluted from the MA-51 affinity column bound insulin with high affinity and this binding was very weakly inhibited by unlabeled IGF-I (Fig. $10 C$ ). Specific IR radioimmunoassay (30) revealed that the MA-51 column absorbed $>99 \%$ of the IR immunoreactivity.

Tyrosine kinase activities of the atypical IGF-I receptor. Employing the atypical IGF-I receptor preparation purified by affinity chromatography, we next carried out studies to determine whether this atypical receptor contained ligand-stimulated tyrosine kinase activity, a characteristic of typical insulin and IGF-I receptors.

When the atypical receptor was allowed to undergo autophosphorylation and then analyzed by SDS-PAGE under re- ducing conditions, it contained a labeled band of $103 \mathrm{kD}$ (Fig. $11 \mathrm{~A})$. The phosphorylation of this $103-\mathrm{kD}$ band increased when the atypical receptor was stimulated with either $100 \mathrm{nM}$ insulin or IGF-I (Fig. 11, left). This band was significantly larger than the typical 95-kD IR $\beta$ subunit (not shown).

Next, the tyrosine kinase activity of the atypical receptor toward the exogenous substrate, poly(Glu-Tyr) 4:1, was studied. Stimulation of the atypical receptor with both insulin and IGF-I produced a dose-dependent increase of ${ }^{32} \mathrm{P}$ incorporation into poly(Glu-Tyr) 4:1 (Fig. 11, right). Stimulation of substrate phosphorylation occurred at lower concentrations of IGF-I than insulin.

Insulin and IGF-I stimulated DNA synthesis in MCF-7 cells. In order to investigate the mitogenic effect of both insulin and IGF-I on MCF-7 cells, we studied $\left[{ }^{3} \mathrm{H}\right]$ thymidine incorporation into DNA. Both insulin and IGF-I stimulated $\left[{ }^{3} \mathrm{H}\right]-$ thymidine incorporation into DNA in a dose-dependent manner; however, IGF-I was 10 fold more potent than insulin (Fig. 12). We next studied the effect of $\alpha$-IR3 on insulin and IGF-Istimulated $\left[{ }^{3} \mathrm{H}\right]$ thymidine incorporation (Fig. 13). MCF-7 cells were stimulated with either $1 \mathrm{nM}$ insulin or $1 \mathrm{nM}$ IGF-I. In the

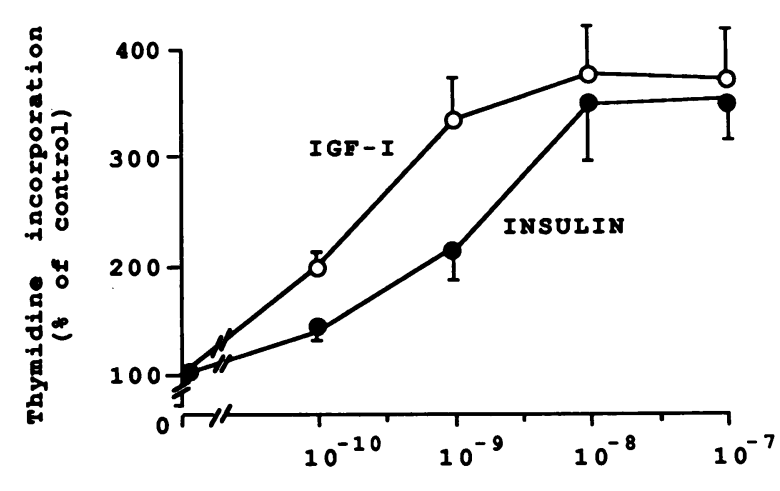

(M)

Figure 12. Stimulation of $\left[{ }^{3} \mathrm{H}\right]$ thymidine incorporation by insulin and IGF-I in MCF-7 breast cancer cells. MCF-7 cells were plated in tissue culture plates in their regular growth medium. After $48 \mathrm{~h}$ medium was replaced with serum free medium. After a further $72 \mathrm{~h}$ the cells were stimulated with either insulin or IGF-I for $24 \mathrm{~h}$. Thymidine incorporation was performed during the last $2 \mathrm{~h}$ of stimulation by adding 0.5 $\mu \mathrm{Ci}$ of $\left[{ }^{3} \mathrm{H}\right]$ thymidine. Cells were then harvested and the rate of $\left[{ }^{3} \mathrm{H}\right]-$ thymidine incorporation was determined as previously described (12). 


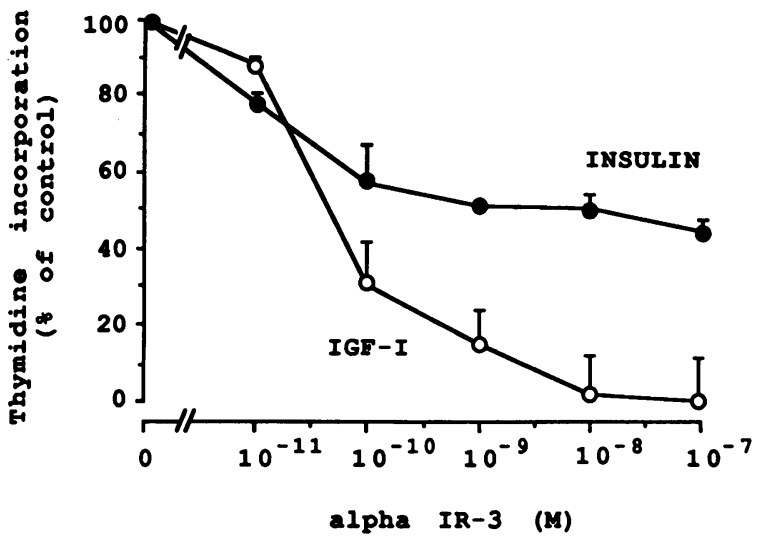

Figure 13. Effect of monoclonal antibody $\alpha$-IR3 on $\left[{ }^{3} \mathrm{H}\right]$ thymidine incorporation stimulated by insulin and IGF-I in MCF-7 breast cancer cells. Cells were cultured in tissue culture plates as described above and stimulated for $24 \mathrm{~h}$ with $1 \mathrm{nM}$ of either insulin or IGF-I in the absence and presence of different concentrations of $\alpha$-IR3. $\left[{ }^{3} \mathrm{H}\right]-$ thymidine incorporation was performed as above described. The amount of $\left[{ }^{3} \mathrm{H}\right]$ thymidine incorporated in absence of either insulin or IGF-I was subtracted to the amount of $\left[{ }^{3} \mathrm{H}\right]$ thymidine incorporated in presence of insulin and IGF-I. Normal mouse IgG at $100 \mathrm{nM}$ produced slight inhibition $(10 \%)$ of $\left[{ }^{3} \mathrm{H}\right]$ thymidine incorporation. Each value is mean $\pm \mathrm{SD}$ of three separate experiments performed in triplicate.

presence of $\alpha$-IR3 there was a complete inhibition of IGF-Istimulated $\left[{ }^{3} \mathrm{H}\right]$ thymidine incorporation at $10 \mathrm{nM}$ of antibody. In contrast, at this $\alpha$-IR3 concentration, the effect of insulin was inhibited only by $50-60 \%$.

\section{Discussion}

Insulin and IGF-I exert their biological effects on cellular metabolism and growth by binding to their distinct plasma membrane receptors which show many similarities of structure and function. Both are $\alpha_{2} \beta_{2}$ tetramers with two extracellular $\alpha$ subunits that bind the hormone and two transmembrane $\beta$ subunits that have tyrosine kinase activity (14). The insulin and type I IGF receptors have a high degree of sequence homology, are similar in molecular size, and signal via activation of tyrosine kinase domains $(14,35-38)$. However, the two receptors functionally are distinct, as assessed by clearly different binding affinities for various ligands (38) and certain anti-receptor antibodies (39). The cloning and sequencing of cDNAs coding for these two receptors have demonstrated that receptors for insulin and IGF-I are products of separate genes $(40,41)$. Insulin and IGF-I themselves have sequence homology and can weakly interact with each other's receptors $(31,42)$.

In the present study, several lines of evidence suggested that the interaction of insulin with MCF-7 cells was predominantly via a receptor that was not the typical insulin receptor. First, competition studies of ${ }^{125}$ I-insulin binding to both intact MCF7 cells and solubilized receptors demonstrated high-affinity insulin binding. However, this binding was inhibited by unlabeled IGF-I at lower concentrations than unlabeled insulin itself. Second, the binding of insulin to MCF-7 cells was markedly inhibited by monoclonal antibody $\alpha$-IR3, an antibody that reacts with the IGF-I receptor but not with the IR. Third, insulin binding was weakly inhibited by the monoclonal antibodies which react with the IR, but not with the IGF-I receptor. Fourth, similar observations were obtained in experiments where membrane receptors of MCF-7 cells were photoaffinity-labeled with photoprobes of insulin and IGF-I. The presence of this atypical receptor in MCF-7 cells was not a general feature of either breast epithelial or breast cancer cells. Typical IR binding was seen with 184 breast epithelial cells as well as in two breast cancer cell lines, ZR-75-1 and T-47D.

The question which arises, therefore, is the nature of the receptor or receptors that insulin binds to in MCF-7 cells. MCF-7 cells have typical IR mRNA and a small fraction of insulin binding was blocked by anti-IR monoclonal antibodies. Moreover, typical IR were isolated by affinity chromatography. Thus a small proportion of ${ }^{125}$ I-insulin binding was most likely to a typical IR. Since MCF-7 cells have IGF-I receptors and insulin is known to weakly bind to IGF-I receptor, one possibility is that the atypical insulin binding was to the IGF-I receptor. For two reasons, this possibility was considered highly unlikely. First, since MCF-7 cells have typical IGF-I receptors and insulin only weakly competed with IGF-I binding to the IGF-I receptor, it is highly unlikely that the high-affinity insulin binding is to the typical IGF-I receptor. Second, 184 breast epithelial cells, ZR-75-1 cells, and T47-D cells also have high concentrations of IGF-I receptors (43), but atypical insulin binding was not observed in these cells.

In vitro, hybrid receptors can be formed between the insulin receptor and the IGF-I receptor $(44,45)$. Moreover, it has been reported that in both human placenta (16) and NIH-3T3 cells transfected with human IR CDNA and expressing human IR(17), IR/IGF-I receptor hybrids can occur in vivo. The possibility was considered, therefore, that the receptor studied herein was a hybrid insulin/IGF-I receptor, and that insulin was binding to the hybrid receptor moeity. For several reasons, this possibility was considered unlikely. First, the monoclonal antibody to the IR employed herein, which interacts with insulin/IGF-I receptor hybrids (44), neither blocked insulin binding nor immunoprecipitated insulin photocross-linked to this receptor. Second, an antipeptide antibody directed against residues 241-251 (22) of the IR failed to immunoprecipitate the $\alpha$ subunit of the receptor photoaffinity-labeled with insulin photoprobe. Third, it has been reported that, when hybrid insulin/ IGF-I receptors are autophosphorylated, there is labeling of two $\beta$-subunit species (45): a smaller one $(95 \mathrm{kD}$ ) representing the IR, and a larger one $(102 \mathrm{kD})$ representing the IGF-I receptor. In our atypical receptor only one $103 \mathrm{kD}$ subunit species was seen. Fourth, this atypical insulin binding was not seen in 184, ZR-75-1, and T47-D cells, all of which also express both insulin and IGF-I receptors.

For several reasons, the most likely possibility is that the atypical insulin binding seen in MCF-7 cells was to a receptor that is related to the IGF-I receptor. First, the cross-linking of the B29-MAB- ${ }^{125}$-insulin revealed a receptor $\alpha$ subunit of 120 $\mathrm{kD}$, a size which is typical for the human placenta IGF-I receptor $\alpha$ subunit, but is smaller than that of the IR $\alpha$ subunit (C. Yip, unpublished data). Moreover, in autophosphorylation studies the $\beta$ subunit was $103 \mathrm{kD}$, a size which is larger than 95 $\mathrm{kD}$ IR $\beta$ subunit. Second, the atypical receptor interacted with the $\alpha$-IR3, an antibody which is directed toward the IGF-I receptor. Therefore, in addition to the typical IGF-I receptor which binds IGF-I but not insulin, another IGF-I receptor exists which binds both IGF-I and insulin. In other tissues, two 
groups have reported atypical receptors that have high-affinity binding for both insulin and IGF-I. In fetal muscle, Alexandrides and Smith (46) reported that both insulin and IGF-I at similar concentrations stimulated the phosphorylation of $105-$ $\mathrm{kD}$ receptor $\beta$ subunit which was more closely related to the IGF-I receptor $\beta$ subunit than the IR. Also, in bovine retina preparations, Waldbilling and Chadder (47) reported that labeled insulin binding was inhibited by unlabeled IGF-I with a potency equal to or greater than that of insulin. These results support the concept that two IGF-I receptors may exist: one with high affinity only for IGF-I, and another with high affinity for both IGF-I and insulin. These two receptors could be produced by the same gene via either processing of IGF-I receptor mRNA or by posttranslational modifications of the IGF-I receptor protein. Although the human genome appears to contain only one IR and one IGF-I receptor gene, it is possible that the atypical receptor expressed in MCF-7 cells could be a product of a distinct gene that encodes a receptor protein that has high-affinity binding for both IGF-I and insulin. Further studies, therefore, including purification and cloning will be necessary to understand the biochemical nature of this atypical IGFI receptor in MCF-7 cells and other tissues.

The atypical IGF-I receptor had intrinsic tyrosine kinase and regulated biological functions. Both receptor autophosphorylation and phosphorylation of an exogenous substrate were stimulated by both insulin and IGF-I. Moreover, in MCF7 cells, both insulin and IGF-I stimulated $\left[{ }^{3} \mathrm{H}\right]$ thymidine incorporation. $\alpha$-IR3 blocked all the effects of IGF-I, but only 50$60 \%$ of the effects of insulin. These studies suggest therefore that insulin exerts a portion of its effect through its own receptor, and another portion through the atypical receptor. Interestingly, Cullen et al. (10) have reported that $\alpha$-IR 3 does not block the effects of insulin on cell growth in MCF-7 cells.

In summary, in MCF-7 cells, there are three functionally distinct receptors: a typical insulin receptor, a typical IGF-I receptor, and an atypical IGF-I-like receptor which binds both insulin and IGF-I with high affinity. The presence of these receptors in MCF-7 cells may explain in part the conflicting results concerning the growth effects of insulin on these cells. Further studies, however, will be necessary to understand the role of these receptors in the growth of MCF-7 cells.

\section{Acknowledgments}

We thank Elaine Jack for technical assistance.

This study was supported by a grant from Medical Research Council, Canada; the Jay Gershow Cancer Fund; the John A. Kerner Foundation; and the Associazione Italiana per la Ricerca sul Cancro (Dr. Milazzo).

\section{References}

1. Hanks, S. K., A. K. Quinn, and T. Hunter. 1988. The protein kinase family: conserved features and deduced phylogeny of the catalytic domains. Science (Wash. DC). 241:42-53.

2. Ullrich, A., J. R. Bell, E. Y. Chen, R. Herrera, L. M. Petruzzelli, T. J. Dull, A. Gray, L. Coussens, Y. C. Liao, M. Tsubokawa, et al. 1985. Human insulin receptor and its relationship to the tyrosine kinase family of oncogenes. Nature (Lond.). 313:756-761.

3. Goldfine, I. D. 1987. The insulin receptor: molecular biology and transmembrane signaling. Endocr. Rev. 8:235-255.

4. Strauss, D. S. 1984. Growth-stimulatory actions of insulin in vitro and in vivo. Endocr. Rev. 5:356-369.

5. Giorgino, F., A. Belfiore, G. Milazzo, A. Costantino, B. Maddux, J. Whittaker, I. D. Goldfine, and R. Vigneri. 1991. Overexpression of insulin receptors in fibroblast and ovary cells induces a ligand-mediated transformed phenotype. Mol. Endorinol. 5:452-459.

6. Papa, V., V. Pezzino, A. Costantino, A. Belfiore, D. Giuffrida, L. Frittitta, G. B. Vannelli, R. Brand, I. D. Goldfine, and R. Vigneri. 1990. Elevated insulin receptor content in human breast cancer. J. Clin. Invest. 85:1503-1510.

7. Lippman, M. E., R. B. Dickson, E. P. Gelmann, N. Rosen, C. Knabbe, S. Bates, D. Bronzert, K. Huff, and A. Kasid. 1987. Growth regulation of human breast carcinomas occurs through regulated growth factor secretion. J. Cell. Biochem. 35:1-16.

8. Osborne, C. K., J. Bolan, M. E. Monaco, and M. E. Lippman. 1976. Hormone responsive human breast cancer in long-term tissue culture: effect of insulin. Proc. Natl. Acad. Sci. USA. 73:4536-4540.

9. Osborne, C. K., M. E. Monaco, M. E. Lippman, and C. R. Kahn. 1978. Correlation among insulin binding, degradation, and biological activity in human breast cancer cells in long term tissue culture. Cancer Res. 38:94-101.

10. Cullen, K. J., D. Yee, W. S. Sey, J. Perdue, B. Hampton, M. E. Lippman, and N. Rosen. 1990. Insulin-like growth factor receptor expression and function in human breast cancer. Cancer Res. 50:48-53.

11. Kull, F. C., S. Jacobs, Y. F. Su, M. E. Svoboda, J. J. Van Wyk, and P. Cuatrecasas. 1983. Monoclonal antibodies to receptors for insulin and somatomedin-C. J. Biol. Chem. 258:6561-6566.

12. Furlanetto, R. W., and J. N. DiCarlo. 1984. Somatomedin-C receptors and growth effects in human breast cancer cells maintained in long-term tissue culture. Cancer Res. 44:2122-2128.

13. Stewart, A. J., M. D. Johnson, F. E. B. May, and B. R. Westley. 1990. Role of insulin-like growth factors and type I insulin-like growth factor receptor in estrogen-stimulated proliferation of human breast cancer cells. J. Biol. Chem. 265:21172-21178.

14. Duronio, V., and S. Jacobs. 1988. Comparison of insulin and IGF-I receptors. In Receptor Biochemistry and Methodology. C. J. Venter and L. C. Harrison, editors. Alan R. Liss, Inc., New York. 12B:3-18.

15. Jonas, A. H. 1988. Heterogeneity of receptors for insulin and insulin-like growth factor I: evidence for receptor subtype. In Receptor Biochemistry and Methodology. C. J. Venter and L. C. Harrison, editors. Alan R. Liss, Inc., New York. 12B:19-36.

16. Soos, M. A., and K. Siddle. 1989. Immunological relationships between receptors for insulin and insulin-like growth factor I. Biochem. J. 263:553-563.

17. Soos, M. A., J. Whittaker, R. Lammers, A. Ullrich, and K. Siddle. 1990. Receptors for insulin and insulin-like growth factor-I can form hybrid dimers. Biochem. J. 270:383-390.

18. Jacobs, S. 1990. Insulin like growth factor I receptor. In Handbook of Experimental Pharmacology. P. Cuatrecasas and S. Jacobs, editors. Springer-Verlag, Inc., New York. 92:267-286.

19. Yip, C. C., C. W. T. Yeung, and M. L. Moule. 1980. Photo affinity labeling of insulin receptor proteins of liver plasma membrane preparations. Biochemistry. 19:70-76.

20. Stampfer, M. R., and J. C. Bartley. 1985. Induction of transformation and continuous cell lines from normal human mammary epithelial cells after exposure to benzo[a]pyrene. Proc. Natl. Acad. Sci. USA. 82:2394-2398.

21. Forsayeth, J. R., A. Montemurro, B. A. Maddux, R. DePirro, and I. D. Goldfine. 1987. Effect of monoclonal antibodies on human insulin receptor autophosphorylation, negative cooperativity, and down-regulation. J. Biol. Chem. 262:4134-4140.

22. Yip, C. C., C. Grunfeld, and I. D. Goldfine. 1991. Identification and characterization of the ligand-binding domain of insulin receptor by use of an anti peptide antiserum against amino acid sequence 241-251 of the $\alpha$-subunit. Biochemistry. 30:695-701.

23. Hartmann, K. K. P., V. Papa, E. J. Brown, U. Doerries, S. M. Rosenthal, and I. D. Goldfine. 1990. A rapid, simple one-step method for isolation of poly(A)+ RNA from cells in monolayer. Endocrinology. 127:2038-2040.

24. Rosenthal, S. M., A. Brunetti, E. J. Brown, P. W. Mamula, and I. D. Goldfine. 1991. Regulation of insulin-like growth factor I receptor expression during muscle cell differentiation. J. Clin. Invest. 87:1212-1219.

25. Sambrook, J., E. F. Fritsch, and T. Maniatis. 1989. Molecular Cloning: A Laboratory Manual. Cold Spring Harbor Laboratory, Cold Spring Harbor, NY.

26. Roth, R. A., D. J. Cassel, B. A. Maddux, and I. D. Goldfine. 1983. Regulation of insulin receptor kinase activity by insulin mimickers and an insulin antagonist. Biochem. Biophys. Res. Commun. 115:245-252.

27. Tollefsen, S. E., K. Thompson, and D. J. Petersen. 1987. Separation of the high affinity insulin-like growth factor I receptor from low affinity binding sites by affinity chromatography. J. Biol. Chem. 262:16461-16469.

28. Forsayeth, J., B. A. Maddux, and I. D. Goldfine. 1986. Biosynthesis and processing of the human insulin receptor. Diabetes. 35:837-846.

29. Lowry, O. H., N. J. Rosebrough, A. L. Farr, and R. J. Randall. 1951. Protein measurement with the Folin phenol reagent. J. Biol. Chem. 260:41284135.

30. Pezzino, V., V. Papa, V. Trischitta, A. Brunetti, P. A. Goodman, M. K. Treutelaar, J. A. Williams, B. A. Maddux, R. Vigneri, and I. D. Goldfine. 1989. 
Human insulin receptor radioimmunoassay: applicability to insulin-resistant states. Am. J. Physiol. 257:E451-457.

31. Froesch, E. R., C. Schmid, J. Schwander, and J. Zapf. 1985. Actions of insulin like growth factors. Annu. Rev. Physiol. 47:443-467.

32. Yip, C. C., H. Hsu, R. G. Patel, D. M. Hawley, B. A. Maddux, and I. D. Goldfine. 1988. Localization of the insulin-binding site to the cysteine-rich region of the insulin receptor $\alpha$-subunit. Biochem. Biophys. Res. Commun. 157:321329.

33. Hawley, D. M., B. A. Maddux, R. G. Patel, K. Y. Wong, P. W. Mamula G. L. Firestone, A. Brunetti, E. Verspohl, and I. D. Goldfine. 1989. Insulin receptor monoclonal antibodies that mimic insulin action without activating tyrosine kinase. J. Biol. Chem. 264:2438-2444.

34. McFarland, K. C., J. Ramachandran, and C. Grunfeld. 1989. Peptidebased radioimmunoassay for insulin receptor: detection of insulin-stimulated downregulation in IM-9 lymphocytes. Diabetes. 38:978-990.

35. Kasuga, M., E. E. Van Obberghen-Schilling, S. P. Nissley, and M. M Rechler. 1988. Demonstration of two subtypes of insulin-like growth factor receptors by affinity cross-linking. J. Biol. Chem. 256:5305-5308.

36. Kasuga, M., F. A. Karlsson, and C. R. Kahn. 1982. Insulin stimulates the phosphorylation of the 95,000-dalton subunit of its own receptor. Science (Wash. DC). 215:185-186.

37. Jacobs, S., F. C. Kull, Jr., H. S. Earp, M. E. Svoboda, J. J. Van Why, and P. Cuatrecasas. 1983. Somatomedin-C stimulates the phosphorylation of the $\beta$-subunit of its own receptor. J. Biol. Chem. 258:9581-9584.

38. Rechler, M. M., J. Zapf, S. P. Nissley, E. R. Froesch, A. C. Moses, J. M. Podskalny, E. E. Schilling, and R. E. Humbel. 1980. Interactions of insulin-like growth factor I and II and multiplication-stimulating activity with receptors and serum carrier proteins. Endocrinology. 107:1451-1459.
39. Kasuga, M., N. Sasaki, C. R. Kahn, S. P. Nissley, and M. M. Rechler. 1983. Antireceptor antibodies as probes of insulin-like growth factor structure. $J$. Clin. Invest. 72:1459-1469.

40. Ebina, Y., L. Ellis, K. Jarnagin, M. Edery, L. Graf, E. Clauser, J. Ou, F. Marsiaz, Y. W. Kan, I. D. Goldfine, et al. 1985. The human insulin receptor cDNA: the structural basis for hormone-activated transmembrane signaling. Cell. 40:747-758.

41. Ullrich, A., A. Gray, A. W. Tam, T. Yang-Feng, M. Tsubokawa, C. Collins, W. Henzel, T. LeBon, S. Kathuria, E. Chen, et al. 1986. Insulin-like growth factor I receptor primary structure: comparison with insulin receptor suggest structural determinants that define functional specificity. EMBO (Eur. Mol. Bio chem. Organ.) J. 5:2503-2512.

42. Rechler, M. M., and S. P. Nissley. 1985. The nature and regulation of the receptors for insulin-like growth factors. Annu. Rev. Physiol. 47:425-442.

43. Pezzino, V., G. Milazzo, L. Frittitta, R. Vigneri, O. Ezaki, M. Kasahara, R. LeBon, I. D. Goldfine, and Y. F. Yamaguchi. 1991. Radioimmunoassay for human insulin-like growth factor-I receptor: applicability to breast carcinoma specimens and cell lines. Metab. Clin. Exp. 40:861-865.

44. Treadway, J. L., B. D. Morrison, I. D. Goldfine, and J. E. Pessin. 1989. Assembly of insulin/insulin-like growth factor I hybrid receptors in vitro. J. Biol. Chem. 264:21450-21453.

45. Moxham, C. P., V. Duronio, and S. Jacobs. 1989. Insulin-like growth factor I receptor $\beta$-subunit heterogeneity. J. Biol. Chem. 264:13238-13244.

46. Alexandrides, T. K., and R. J. Smith. 1989. A novel fetal insulin-like growth factor (IGF) I receptor. J. Biol. Chem. 264:12922-12930.

47. Waldbillig, R. J., and G. J. Chader. 1988. Anomalous insulin binding activity in the bovine neural retina: a possible mechanism for regulation of receptor binding specificity. Biochem. Biophys. Res. Commun. 151:1105-1112. 